\title{
Pre- and Post-Ischemic Administration of Dizocilpine (MK-801) Reduces Cerebral Necrosis in the Rat
}

\author{
M.R. Rod and R.N. Auer
}

\begin{abstract}
The purpose of this study was to determine the effectiveness of the non-competitive N-methyl-D-aspartate receptor antagonist dizocilpine, or (+)-5-methyl-10,11-dihydro-5H-dibenzo(a,d)cyclohepten-5,10-imine (MK-801) in mitigating ischemic neuronal necrosis in the rat. Ten minutes of transient forebrain ischemia was induced by a combination of bilateral carotid clamping and hypotension to $50 \mathrm{~mm} \mathrm{Hg}$. Control animals received intravenous saline, whereas treated animals received dizocilpine, either $1 \mathrm{mg} / \mathrm{kg}$ iv $20 \mathrm{~min}$. pre ischemia, $1 \mathrm{mg} / \mathrm{kg}$ iv $20 \mathrm{~min}$. post ischemia, $10 \mathrm{mg} / \mathrm{kg}$ iv $20 \mathrm{~min}$. post ischemia, $10 \mathrm{mg} / \mathrm{kg}$ ip 2 hrs. post ischemia, $10 \mathrm{mg} / \mathrm{kg}$ ip 24 hrs. post ischemia. The groups receiving dizocilpine before or up to $20 \mathrm{~min}$. after ischemia all showed a significant reduction in the number of dead neurons as assessed by quantitative histopathology in hippocampus, caudate nucleus and cerebral cortex after one week of recovery. However, dizocilpine administered either 2 or $24 \mathrm{hrs}$. after ischemia afforded no protection. These results suggest that the potent non-competitive NMDA antagonist dizocilpine may have some value in protecting the brain from hippocampal and cortical neuronal necrosis after a short insult consisting of dense transient cerebral ischemia. Noteworthy is the fact that pharmacologic intervention in the post-ischemic period was successful in preventing neuronal death, provided that drug administration occurred within dizocilpine's "therapeutic window".
\end{abstract}

RÉSUMÉ: L'administration pré- et post-ischémique de dizocilpine (MK-801) diminue la nécrose cérébrale chez le rat Le but de cette étude était de déterminer l'efficacité de l'antagoniste noncompétitif du récepteur N-méthyl-Daspartate, la dizocilpine, ou (+)-5-méthyl-10, 11-dihydro-5H-dibenzo (a, d) cyclohepten-5, 10-imine (MK-801) afin d'atténuer la nécrose ischémique neuronale chez le rat. Une ischémie transitoire d'une durée de dix minutes au niveau du cerveau antérieur a été induite par l'obstruction bilatérale des carotides au moyen de clamps associée à une hypotension à $50 \mathrm{~mm} \mathrm{Hg}$. Les animaux contrôles ont reçu du salin intraveineux, alors que les animaux traités ont reçu de la dizocilpine, soit $1 \mathrm{mg} / \mathrm{kg}$ iv $20 \mathrm{~min}$ pré-ischémie, $1 \mathrm{mg} / \mathrm{kg}$ iv $20 \mathrm{~min}$ post-ischémie, $10 \mathrm{mg} / \mathrm{kg}$ iv $20 \mathrm{~min}$ postischémie, $10 \mathrm{mg} / \mathrm{kg}$ ip $2 \mathrm{hrs}$ post-ischémie, $10 \mathrm{mg} / \mathrm{kg}$ ip $24 \mathrm{hrs}$ post-ischémie. Les groupes recevant de la dizocilpine avant et jusqu'à 20 min après l'ischémie ont tous présenté une diminution significative du nombre des neurones morts évalué par examen histopatholgique quantitatif de l'hippocampe, du noyau caudé et du cortex cérébral après une semaine de convalescence. Cependant, la dizocilpine administrée soit 2 ou 24 hrs après l'ischémie ne conférait aucune protection. Ces observations suggèrent que la dizocilpine, un antagoniste non-compétitif du NMDA, peut être d'une certaine utilité pour protéger le cerveau de la nécrose neuronale au niveau de l'hippocampe et du cortex après une agression de courte durée consistant en une ischémie cérébrale transitoire intense. Il est à souligner que l'intervention pharmacologique dans la période post-ischémique a été utile pour prévenir la mort neuronale, à la condition que la médication soit administrée en dedans de la fenêtre thérapeutique de la dizocilpine.

Can. J. Neurol. Sci. 1989; 16:340-344

There is mounting evidence for a role of the N-Methyl-DAspartate (NMDA) subtype of excitatory neuronal receptors in the pathophysiology of ischemic brain damage..$^{1-3}$ The concept of receptor mediated neuronal necrosis opens up therapeutic possibilities for pharmacologic blockade of the receptors mediating ischemic neuronal death.

Dizocilpine, or MK-801 is an effective blocker of central NMDA receptors 4.5 even when given parenterally, due to its lipophilia and penetration of the blood brain barrier. ${ }^{6}$ Originally studied for its pronounced anticonvulsant, sympathomimetic and anxiolytic properties, ${ }^{7-9}$ pharmacologic studies thereafter found dizocilpine to be a potent, stereoselective, non-competitive antagonist of the N-methyl-D-aspartate (NMDA) receptor, $4,5,10,11$ exerting its block in a use-dependent manner.6,12-14 Numerous groups have shown dizocilpine to be effective in reducing or even abolishing the neuronal necrosis seen after episodes of either global $2,5,15$ or focal ${ }^{16-18}$ ischemia. Based on this, we investigated the potential of several regimens of the non-competitive NMDA antagonist dizocilpine in protecting against ischemic neuronal necrosis. The results suggest

From the Departments of Pathology and Clinical Neurosciences, Neuroscience Research Group, Health Sciences Centre, University of Calgary, Calgary, Alberta, Canada T2N 4Ni

Received January 23, 1989. Accepted April 3, 1989

Reprint requests to: Dr. R.N. Auer, Neuropathology, Health Sciences Centre, 3330 Hospital Drive N.W., Calgary, Alberta, Canada T2N 4N1 
dizocilpine is effective in the rat if administered sufficiently early after ischemia.

\section{Materials AND Methods}

Ischemia was induced in 39 male Wistar rats $(277-506 \mathrm{~g})$ by a modification of the previously described model of Smith and co-workers. ${ }^{19}$ Essentially, transient forebrain ischemia was induced by a combination of carotid clamping and hypotension. Rats were anaesthetized in $3 \%$ halothane (MTC Pharmaceuticals, Mississauga, Ont.), intubated and ventilated on a Starling type ventilator, using a $2: 1 \quad \mathrm{~N}_{2} \mathrm{O}: \mathrm{O}_{2}$ mixture containing $0.7 \%$ halothane. A tail vein was cannulated and continuous infusion of suxamethonium chloride $(2 \mathrm{mg} / \mathrm{hr}$.) was used to maintain paralysis during surgery. The ventral tail artery was cannulated and blood pressure (BP) was recorded via a Statham transducer (Gould P50, Oxnard, Calif.). BP readings were automatically digitized every 6 seconds and recorded on the hard disk of a computer. A central venous catheter was inserted into the right jugular vein and attached to a pre-warmed heparinized syringe.

Halothane was discontinued and after a period of physiologic stabilization of roughly 20 minutes, rats were given $5 \mathrm{mg} / \mathrm{kg}$ iv Trimethaphan (Arfonad, Hoffman-Laroche, Toronto Ont.) to counteract the Cushing response during carotid clamping. The ganglion blocker was used to reduce the catecholaminergic response to carotid clamping, and allow for maintainance of the $\mathrm{BP}$ at $50 \mathrm{~mm} \mathrm{Hg}$ by controlled exsanguination. During the subsequent drop in blood pressure, blood was withdrawn into the heparinized syringe to further lower the BP to $50 \mathrm{~mm} \mathrm{Hg}$, at which time two Moria vessel clamps were placed on the carotid arteries. BP was maintained at $50 \mathrm{~mm} \mathrm{Hg}$ by withdrawal and reinfusion of the shed blood via the central venous catheter.

After 10 minutes of ischemia, the carotid clamps were released and the exsanguinated blood was reinfused. Control animals received no drug, while treated animals received dizocilpine (MK-801, (+)-5-methyl-10,11-dihydro-5H-dibenzo(a,d)cyclohepten-5,10-imine maleate) according to the following regimens: (A) $1 \mathrm{mg} / \mathrm{kg}$ iv $20 \mathrm{~min}$. pre-ischemia, (B) $1 \mathrm{mg} / \mathrm{kg}$ iv $20 \mathrm{~min}$. post-ischemia, (C) $10 \mathrm{mg} / \mathrm{kg}$ iv $20 \mathrm{~min}$. post-ischemia, (D) $10 \mathrm{mg} / \mathrm{kg}$ ip $2 \mathrm{hrs}$. post-ischemia, (E) $10 \mathrm{mg} / \mathrm{kg}$ ip $24 \mathrm{hrs}$. post-ischemia.

Animals were extubated when respiratory efforts were resumed, and allowed to recover for a seven day survival period. All rats were euthanized one week post-ischemia by anaesthesia in $2-3 \%$ halothane, intubation, thoracotomy, and transcardiac perfusion with $4 \%$ formaldehyde, phosphate-buffered to $\mathrm{pH} 7.35$.

The brains were removed one day after perfusion fixation, processed in graded ethanols and xylol, and embedded in paraffin. Subserial sectioning was performed in order to obtain sections from the cerebral cortex, hippocampus, caudate nucleus, diencephalon, brainstem, and cerebellum in all animals.

The ischemia model used produces dense cerebral ischemia at the septal hippocampal levels 1 to 4 (Figure 1) but temporally, blood flow from the posterior circulation results in borderline ischemia at levels 5 and $6^{19}$ with a resultant paucity and variability of damage. For this reason, only hippocampal septotemporal levels 1 - 4 were quantitatively assessed for histopathologic damage. Neuronal death was quantitated by one

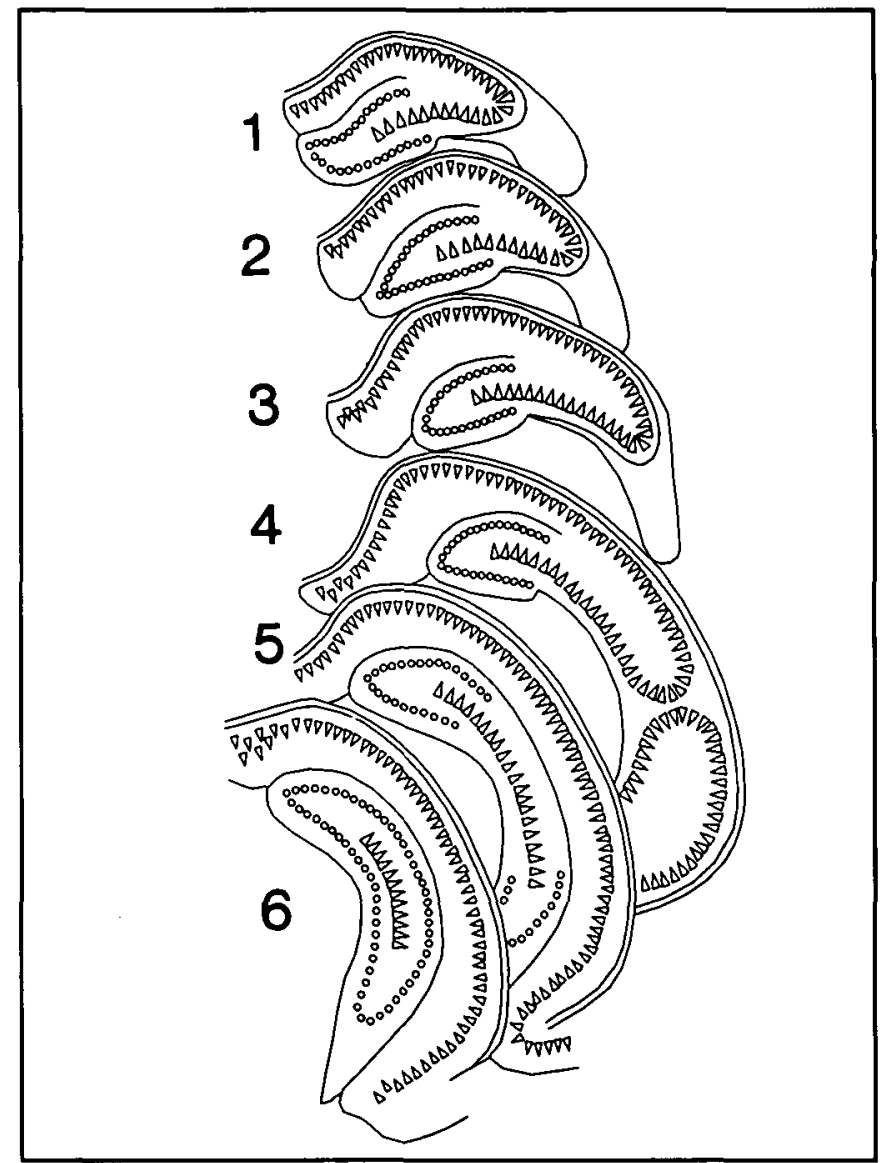

Figure I - Hippocampal levels shown diagrammatically to indicate the septo-temporal levels sampled for histologic quantification. Data on hippocampal neuronal loss was derived from levels $l$ - 4. as little damage was seen at levels 5 \& 6 , likely related to the incomplete ischemia produced at these levels in this model.'

of us (MR) blinded to the animal group. Counts of acidophilic neurons, known to be necrotic from previous work, ${ }^{20}$ were obtained by direct visual examination of hippocampal levels 1 to 4 (Figure 1), chosen from sections taken every $200 \mu \mathrm{m}$ throughout the hippocampus. The nuclear and cytoplasmic outlines were indistinct in the acidophilic neurons, indicating cytorrhexis and karyorrhexis.

In the cerebral cortex, sampled at the coronal level of the subfornical organ, the total number of acidophilic neurons in all cortical laminae was summed for each hemisphere. The caudate nucleus was sampled at the coronal level of the septal nuclei at their widest point. Two dorsolateral $630 \mu \mathrm{m}$ diameter microscopic fields were examined bilaterally.

\section{RESULTS}

Clinically, the course of treated and untreated rats was different. Untreated ischemic control animals could be extubated within $30 \mathrm{~min}$. of the ischemic episode. Rats treated with intravenous (groups B-D) or intraperitoneal (groups $E$ and F) dizocilpine could not be extubated until $30-90 \mathrm{~min}$. after surgery due to slower recovery of respiratory efforts, and remained in a cataleptic state for 24 - 48 hrs. after surgery. They failed to groom themselves, and lay motionless in the cage with 

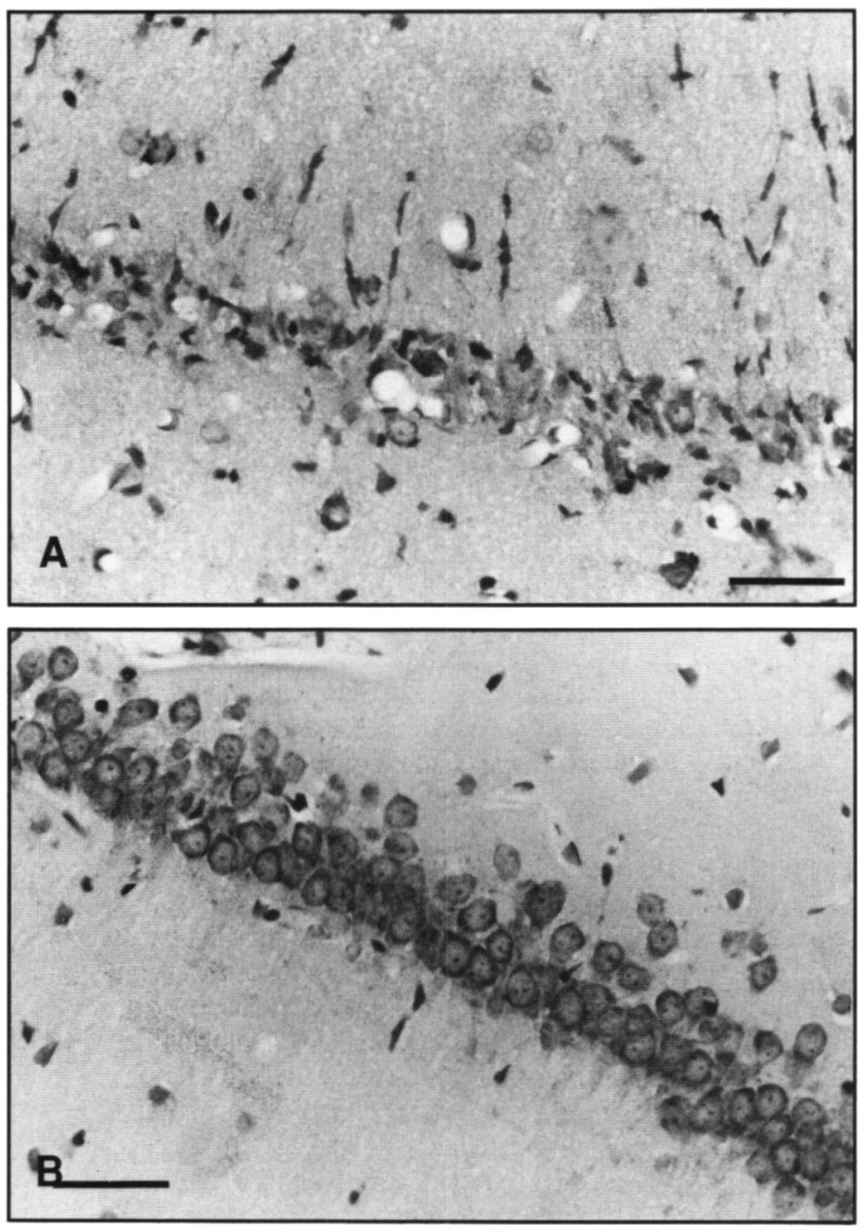

Figure 2 - High-power photomicrograph of the hippocampal CAI pyramidal cell band in an untreated animal $(A)$, and a rat treated with dizocilpine (B) $10 \mathrm{mg} / \mathrm{kg}$ iv $20 \mathrm{~min}$. after $10 \mathrm{~min}$. of transient forebrain ischemia. One week survival. $2 \%$ phloxine, $0.1 \%$ cresyl violet. Bars $=100 \mu \mathrm{m}$.

the eyes open, for the first day. On the second day following ischemia, dizocilpine treated rats showed ataxia on walking, with a poor righting reflex. All dizocilpine treated rats became indistinguishable from untreated ischemic controls by the 4th postischemic day. The neurobehavioural effects of dizocilpine, and their time course thus resembled those seen in naive rats given dizocilpine 21 and may be accounted for by NMDA receptor blockade. $21-23$

Histologically, a protective effect was seen in the hippocampus (Figure 2), where low dose dizocilpine ( $1 \mathrm{mg} / \mathrm{kg}$ iv) administered either pre- or post-ischemically significantly reduced the number of necrotic neurons. High dose dizocilpine $(10 \mathrm{mg} / \mathrm{kg})$ administered in the post-ischemic period significantly reduced neuronal necrosis $(\mathrm{p}<0.001)$ but only when given $20 \mathrm{~min}$. post ischemia (Figure 3). Neither the group treated 2 hr. nor $24 \mathrm{hrs}$. after ischemia showed a significant difference in quantitated hippocampal necrosis from untreated control animals (Figure 3).

Extra-hippocampal damage was seen in the cerebral cortex of $5 / 6$ control animals and in 11/33 of dizocilpine treated animals. Within any of the treated groups, individual animals showing hippocampal protection also exhibited neocortical protection (see Table 1). However, taken as a group, only low dose dizocilpine $(1 \mathrm{mg} / \mathrm{kg})$ and high dose dizocilpine $(10 \mathrm{mg} / \mathrm{kg})$ both given $20 \mathrm{~min}$. post-ischemia reduced damage significantly below that seen in controls $(p<0.0 .1$ and $p<0.0005$ respectively).

In the caudate nucleus damage was only seen in two animals. One control rat had $6 \%$ neuronal necrosis while a rat given a low dose dizocilpine $(1 \mathrm{mg} / \mathrm{kg})$ post-ischemia showed only scattered necrotic striatal neurons.

\section{Discussion}

The most significant finding in this study is that dizocilpine has the ability to reduce or abolish neuronal necrosis in the cerebral cortex and hippocampus when administered after dense, transient forebrain ischemia. Our findings in the rat that pharmacologic intervention is ineffective 2 hrs. or longer after the ischemic insult contrasts with those obtained in the gerbil by Gill and co-workers, 15 who found that dizocilpine afforded some degree of neuroprotection if administered up to $24 \mathrm{hrs}$. after an ischemic insult. The fact that both the $2 \mathrm{hr}$. and $24 \mathrm{hr}$. post-ischemia groups were given the dizocilpine intra-peritoneally cannot explain our results, since the cataleptic state of the animals indicates adequate central penetration of the drug, which readily crosses the blood brain barrier. More likely is the explanation that that the drug arrived in the CNS after irreversible cytotoxic events had already occurred.

Dizocilpine has demonstrated a neuroprotective effect in several animal models, including neonatal hypoxia-ischemia, ${ }^{24}$ transient forebrain ischemia in the gerbil, 2,15 and focal cerebral ischemia in the cat. 16,17 The present findings extend these observations to forebrain ischemia in the rat, and further support the notion that post-ischemic intervention is practical and effective in reducing brain damage.

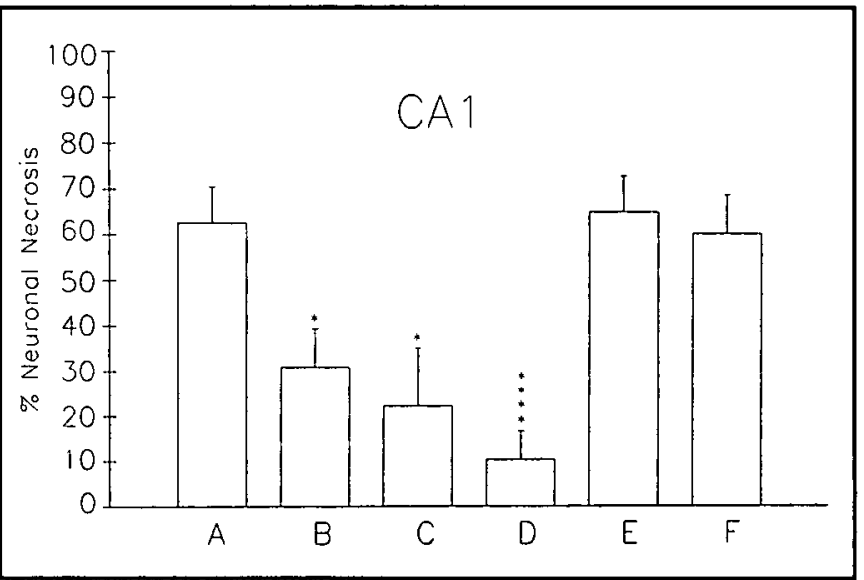

Figure 3 -Percent necrotic neurons in the entire CAI pyramidal cell band. The mean percentages for each group ( $\pm S E M$ ) are shown. but were converted using the arcsine rransformation ${ }^{39}$ to allow the use of an independent Student's T-test. Group A, control, $10 \mathrm{~min}$. ischemia, no dizocilpine. Group $B, 1 \mathrm{mg} / \mathrm{kg}$ iv dizocilpine $20^{\prime} \mathrm{pre}$ ischemia. Group C, $1 \mathrm{mg} / \mathrm{kg}$ iv dizocilpine $20^{\prime}$ post-ischemia. Group D. $10 \mathrm{mg} / \mathrm{kg}$ iv dizocilpine $20^{\prime}$ post-ischemia. Group E, $10 \mathrm{mg} / \mathrm{kg}$ ip dizocilpine 2 hrs. post-ischemia. Group $F, 10 \mathrm{mg} / \mathrm{kg}$ ip dizocilpine 24 hrs. post-ischemia. Neuronal necrosis is reduced by dizocilpine in the pretreated group $B(p<0.05)$, and the 20 min. postireated groups $C(p<0.05)$ and $D(p<0.001)$, independent Students $T$ test. 
Table 1: Relationship Between Dizocilpine Administration and Number of Cerebral Hemispheres Exhibiting Dead Neurons

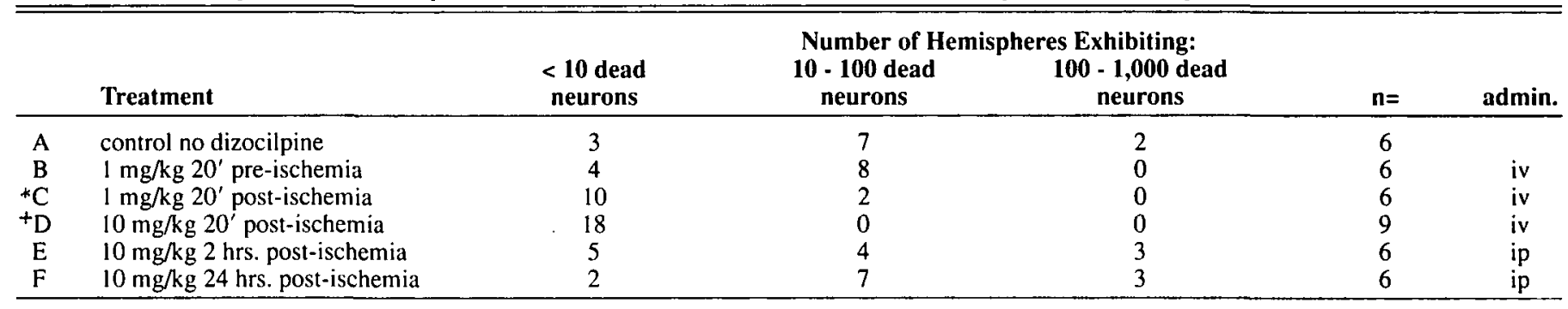

$\left.\begin{array}{l}* p<0.01 \\ +p<0.0005\end{array}\right\}$ Fisher's Exact Test

The post-ischemic time interval after these ischemic insults during which dizocilpine remains effective varies in the literature. 15.17 Using a model of neonatal hypoxia/ischemia, one group showed that dizocilpine was capable of reducing the volume of hemispheric necrosis when administered $11 / 4 \mathrm{hrs}$. into the insult, with a lesser protective effect at $11 / 2 \mathrm{hrs}$. or $21 / 2 \mathrm{hrs} .{ }^{24}$ It has also been shown that dizocilpine reduces the volume of ischemic damage in permanent focal ischemia in the cat, when given 2 hrs. after the onset of occlusion. ${ }^{17}$ In a gerbil model of transient forebrain ischemia another group showed a protective effect as late as $15-24$ hrs. post-ischemia, with a dose-dependent reduction in hippocampal CAl necrosis. 15 Taken together with the present findings, these results indicate that a definite time interval for the post-ischemic "temporal window" cannot be given, but it is clear from all the studies that the effectiveness of dizocilpine diminishes beyond a post-ischemic period of one or two hours.

The fact that dizocilpine is at all effective in preventing neuronal death when given after the ischemic episode can be attributed to the now well known phenomenon of delayed neuronal death after ischemia,25,26 in which neurons die after a post-ischemic interval rather than immediately after ischemia. This phenomenon of maturation of ischemic damage is now well described in several animal species $27-29$ and probably occurs as well in humans suffering brain damage due to cardiac arrest. 30

The apparent universality of the phenomenon of the delayed nature of ischemic brain damage in mammalian species, and the effectiveness of dizocilpine even after ischemia, justifies a guarded optimism for the treatment of ischemic brain damage in clinical situations. The human hippocampus is consistently damaged in global ischemia, $30-35$ giving rise to variably disabling degrees of memory deficit. $32,36,37$ In the rat, learning and memory function are similarly sensitive to subtotal damage limited to the hippocampus. ${ }^{38}$ Should it be possible to demonstrate neurologic improvement in additional to reduced histologic damage in experimental animals, post-ischemic therapy with intravenous dizocilpine might be considered in man.

\section{ACKNOWLEDGEMENTS}

This work was supported by the Medical Research Council of Canada (MA-9935). Dizocilpine was a gift from Merck, Sharpe \& Dohme.

\section{REFERENCES}

1. Simon RP, Swan JH, Griffiths T, et al. Blockade of N-methyl-Daspartate receptors may protect against ischemic damage in the brain. Science 1984; 226: 850-852.

2. Gill R, Foster AC, Woodruff GN. Systemic administration of MK801 protects against ischemia-induced hippocampal neurodegeneration in the gerbil. J Neurosci 1987; 7: 3343-3349.

3. Rothman S. Synaptic release of excitatory amino acid neurotransmitter mediates anoxic neuronal death. J Neurosci 1984; 4: 1884-1891.

4. Wong EHF, Kemp JA, Priestley T, et al. The anticonvulsant MK801 is a potent $\mathrm{N}$-methyl-D-aspantate antagonist. Proc Natl Acad Sci USA 1986; 83: 7104-7108.

5. Woodruff GN, Foster AC, Gill R, et al. The interaction between MK-801 and receptors for N-methyl-D-aspartate: Functional consequences. Neuropharmacology 1987; 26: 903-909.

6. Foster AC, Gill R, Kemp JA, et al. Systemic administration of MK-801 prevents $\mathrm{N}$-methyl-D-aspartate-induced neuronal degeneration in rat brain. Neurosci Lett 1987; 76:307-311.

7. Clineschmidt BV, Martin GE, Bunting PR. Anticonvulsant activity of (+)-5-methyl-10,11-dihydro-5H-dibenzo[a,d]cyclohepten5,10-imine (MK-801), a substance with potent anticonvulsant, central sympathomimetic, and apparent anxiolytic properties. Drug Dev Res 1982; 2: 123-134.

8. Clineschmidt BV, Martin GE, Bunting PR, et al. Central sympathomimetic activity of (+)-5-methyl-10,11-dihydro-5H. dibenzo[a,d]cyclohepten-5,10-imine (MK-80l), a substance with potent anticonvulsant, central sympathomimetic, and apparent anxiolytic properties. Drug Dev Res 1982; 2: 135-145.

9. Clineschmidt BV, Williams M, Witoslawski JJ, et al. Restoration of shock-suppressed behavior by treatment with (+)-5-methyl10,11-dihydro-5H-dibenzo[a,d]cyclohepten-5,10-imine (MK801 ), a substance with potent anticonvulsant, central sympathomimetic, and apparent anxiolytic properties. Drug Dev Res 1982; 2: 147-163.

10. Coan EJ, Saywood W, Collingridge GL. MK-801 blocks NMDA receptor-mediated synaptic transmission and long term potentiation in rat hippocampal slices. Neurosci Lett 1987; 80:111-114.

11. Olney J, Price M, Salles S, et al. MK-801 powerfully protects against $\mathrm{N}$-methyl aspartate neurotoxicity. Eur J Pharmacol 1987; 141: 357-361.

12. Foster $A C$, Wong EHF. The novel anticonvulsant MK-80I binds to the activated state of the $\mathrm{N}$-methyl-D-aspartate receptor in rat brain. Br J Pharmacol 1987; 91: 403-409.

13. Davies SN, Martin D, Millar JD, et al. Differences in results from in vivo and in vitro studies on the use-dependency of $\mathrm{N}$-methylaspartate antagonism by $\mathrm{MK}-801$ and other phencyclidine receptor ligands. Eur J Pharmacol 1988; 145: 141-151.

14. McKernan RM, Castro S, Poat JA, et al. Solubilization of the Nmethyl-D-aspartate receptor channel complex from rat and porcine brain. J Neurochem 1989; 52: 777-785. 
15. Gill R, Foster AC, Woodruff GN. MK-801 is neuroprotective in gerbils when administered in the post-ischaemic period. Neuroscience 1988; 25: 847-855.

16. Ozyurt E, Graham DI, Woodruff GN, et al. Protective effect of the glutamate antagonist, MK-801 in focal cerebral ischemia in the cat. J Cereb Blood Flow Metabol 1988; 8: 138-143.

17. Park CK, Nehls DG, Graham DI, et al. Focal cerebral ischaemia in the cat: Treatment with the glutamate antagonist MK-801 after induction of ischaemia. J Cereb Blood Flow Metabol 1988; 8: 757-762.

18. Kochar A, Zivin JA, Lyden PD, et al. Glutamate antagonist therapy reduces neurologic deficits produced by focal central nervous system ischemia. Arch Neurol 1988; 45: 148-153.

19. Smith M-L, Bendek, Dahlgren N, et al. Models for studying longterm recovery following forebrain ischemia in the rat. 2. A 2vessel occlusion model. Acta Neurol Scand 1984; 69: 385-401.

20. Auer RN, Kalimo H, Olsson Y, et al. The temporal evolution of hypoglycemic brain damage. I. Light and electron microscopic findings in the rat cerebral cortex. Acta Neuropathol (Berl) 1985; 67: 13-24

21. Whishaw IQ, Auer RN. Immediate and long-lasting effects of MK801 on motor activity, spatial navigation in a swimming pool and EEG in the rat. Psychopharmacology 1989; in press.

22. Koek W, Kleer E, Mudar PJ, et al. Phencyclidine-like catalepsy induced by the excitatory amino acid antagonist DL-2-amino-5phosphonovalerate. Behav Brain Res 1986; 29: 257-259.

23. Koek W, Woods JH, Mattson MV, et al. Excitatory amino acid antagonists induce a phencyclidine-like catalepsy in pigeons: structure-activity studies. Neuropharmacology 1987; 26: 1261 1265.

24. McDonald JW, Silverstein FS, Johnston MV. MK-801 protects the neonatal brain from hypoxic-ischemic damage. Eur $J$ Pharmacol 1987; 140: 359-361.

25. Ito U, Spatz M, Walker TJ Jr, et al. Experimental cerebral ischemia in Mongolian gerbils. I. Light microscopic observations. Acta Neuropathol (Berl) 1975; 32: 209-223.

26. Kirino T. Delayed neuronal death in the gerbil hippocampus following ischemia. Brain Res 1982; 239: 57-69.
27. Kirino T, Sano K. Selective vulnerability in the gerbil hippocampus following transient ischemia. Acta Neuropathol (Berl) 1984; 62: 201-208.

28. Kirino T, Sano K. Fine structural nature of delayed neuronal death following ischemia in the gerbil hippocampus. Acta Neuropathol (Berl) 1984; 62: 209-218.

29. Kirino T, Tamura A, Sano K. Delayed neuronal death in the rat hippocampus following transient forebrain ischemia. Acta Neuropathol (Berl) 1984; 64: 139-147.

30. Petito CK, Feldman E, Pulsinelli WA, et al. Delayed hippocampal damage in humans following cardiorespiratory arrest. Neurology 1987; 37: 1281-1286.

31. Mandel MM, Berry RG. Human brain changes in cardiac arrest. Surg Gynecol Obstet 1959; 108: 692-696.

32. Muramoto O, Kuru Y, Sugishita M, et al. Pure memory loss with hippocampal lesions. A pneumoencephalographic study. Arch Neurol 1979; 36: 54-56.

33. Cummings JL, Tomiyasu U, Read S, et al. Amnesia with hippocampal lesions after cardiopulmonary arrest. Neurology 1984; 34: 679-681

34. Zola-Morgan S, Squire LR, Amaral DG. Human amnesia and the medial temporal region: Enduring memory impairment following a bilateral lesion limited to field CA1 of the hippocampus. J Neurosci 1986; 6: 2950-2967.

35. Cole G, Cowie VA. Long survival after cardiac arrest: Case report and neuropathological findings. Clin Neuropathol 1987; 6: 104109.

36. Earnest M, Yarnell PR, Merrill S, et al. Long-term survival and neurologic status after resuscitation from out-of-hospital cardiac arrest. Neurology 1980; 30: 1298-1302.

37. Volpe BT, Hirst W. The characterization of an amnesic syndrome following hypoxic ischemic injury. Arch Neurol 1983; 40: 436440.

38. Auer RN, Jensen ML, Whishaw IQ. Neurobehavioural deficit due to ischemic brain damage limited to half of the CAI sector of the hippocampus. J Neurosci 1989; (in press).

39. Zar JH. Data transformations. Biostatistical Analysis. New Jersey, U.S.A.: Prentice-Hall, Inc., 1974; 185-186. 